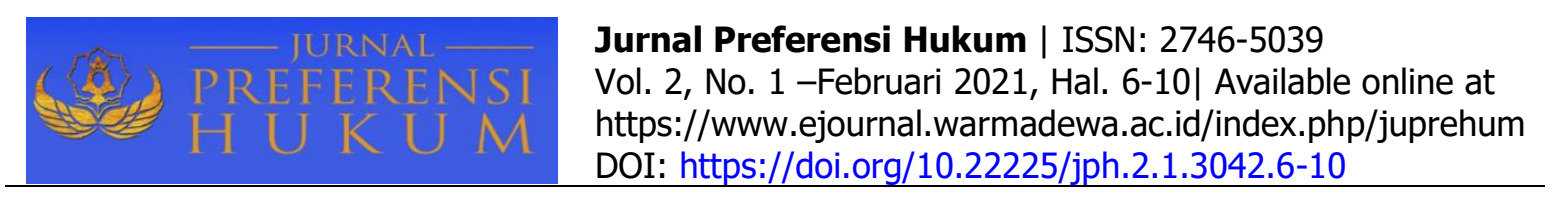

\title{
ASAS KEADILAN PEMUNGUTAN PAJAK DALAM PERATURAN PEMERINTAH NO 23 TAHUN 2018 TENTANG PAJAK PENGHASILAN
}

\author{
Made Dwi Surya Suasa, I Made Arjaya, I Putu Gede Seputra \\ Fakultas Hukum Universitas Warmadewa Denpasar-Bali, Indonesia
}

\begin{abstract}
Abstrak
Tahun 2018, pemerintah menerbitkan peraturan baru dibidang perpajakan yang diharapkan membawa dampak baik seperti pajak pendapatan. Aturan yang ditetapkan dalam pemerintah peraturan nomor 23 Tahun 2018 tentang pajak penghasilan atas pendapatan usaha diterima atau disediakan pembayar pajak yang telah ditentukan bruto distribusi (Peraturan Pemerintah Nomor 23 Tahun 2018). Penelitian ini bertujuan untuk mendeskripsikan proses penerapan asas keadilan dalam pemungutan pajak penghasilan, yang kedua menjelaskan Peraturan Pemerintah Nomor 23 Tahun 2018 tentang Pajak PenghasiIan atas Penghasilan dari usaha yang diterima atau diperoIeh Wajib Pajak yang Memiliki Peredaran Bruto Tertentu sudah memenuhi asas keadilan dalam pemungutan pajak. Penelitian ini didesain menggunakan penelitian hukum normatif atau penelitian kepustakaan yang diIakukan dengan cara meneIiti bahan pustaka atau data sekunder saja. Pendekatannya adalah pendekatan Peraturan Pemerintah, Pendekatan undang-undang. Hasil penelitian menunjukkan bahwa Penerapan asas keadilan dalam pemungutan pajak penghasilan, yaitu asas Equality (kesamaan), asas Certainty (kepastian), asas Conveniency of Payment (Kesenangan), dan asas Low Cost of Collection (Efisiensi). Asas yang sangat berhubungan dengan asas keadilan pemungutan pajak adalah Certainty (Asas Kepastian) guna menjamin pelaksanaan pajak kepada setiap wajib pajak, selanjutnya Peraturan Pemerintah No 23 Tahun 2018 pajak penghasilan dari usaha yang di peroleh wajib pajak telah memenuhi asas keadilan dalam pemungutan pajak. Hal ini dikarenakan adanya penurunan tarif pajak penghasilan final $1 \%$ menjadi $0,5 \%$ dari omzet, harus wajib di dibayarkan setiap bulan, jangka waktu pengenaan tarif Pajak Penghasilan Final 0,5\% baik WP orang pribadi atau badan
\end{abstract}

Kata kunci: Pajak penghasiIan; PP Nomor 23 tahun 2018; Distribusi bruto spesifik; keadilan.

\begin{abstract}
In 2018, the government issued new regulations in the field of taxation which are expected to bring good impacts such as income tax. The rules stipulated in government regulation number 23 of 2018 concerning income tax on business income are received or provided by taxpayers who have been determined by the gross distribution (Government Regulation Number 23 of 2018). This study aims to describe the process of applying the principle of justice in income tax collection, the second explains Government Regulation Number 23 of 2018 concerning Income Tax on Income from business received or earned by Taxpayers Who Have Certain Gross Circulation already fulfills the principle of fairness in tax collection. This research is designed to use normative legal research or library research which is done by examining library materials or secondary data only. The approach is a Government Regulation approach, a statutory approach. The results showed that the application of the principle of justice in income tax collection, namely the principle of Equality, the principle of Certainty, the principle of convenience of payment, and the principle of Low Cost of Collection (Efficiency). The principle that is closely related to the principle of fairness of tax collection is Certainty in order to guarantee the implementation of taxes to each taxpayer, furthermore Government Regulation No. 23 of 2018 income tax from businesses obtained by taxpayers has fulfilled the principle of fairness in tax collection. This is due to a decrease in the final income tax rate of $1 \%$ to $0.5 \%$ of turnover, must be paid every month, the period of imposition of the Final Income Tax rate is $0.5 \%$ for both individual and corporate taxpayers.
\end{abstract}

Keywords: income tax; PP Number 23 of 2018; Specific gross distribution; justice.

\section{PENDAhuluan}

Indonesia adalah Negara hukum dan segala bentuk tindakan yang diambil oleh pemerintah maupun masyarakat haruslah berdasarkan norma hukum yang berlaku (Arliman. S, 2019). Hukum merupakan petunjuk hidup yang berisi perintah dan larangan yang bertujuan untuk mengatur masyarakat. Sehingga sudah seharusnya hukum ditaati oleh seluruh anggota masyarakat tanpa terkecuali dan apabila terjadi pelanggaran akan timbul sanksi yang bersifat tegas serta nyata. Hukum pajak merupakan jenis hukum yang berlaku di Indonesia. 
Pajak merupakan iuran wajib untuk negara terutang menurut peraturan oleh seorang wajib pajak (WP), yang dapat langsung ditunnjuk yang tidak mendapatkan prestasi yang digunakan untuk membiaya pengeluaran umum untuk menyelenggarakan pemerintah. Institusi pemerintah Indonesia bertugas untuk menghimpun penerimaan pajak sekaligus menyelenggarakan fungsi administrasi perpajakan adalah Direktorat Jendral Pajak (DJP). (Safrina et al., 2018). Dalam menjalankan fungsinya Direktorat Jendral Pajak sejatinya menerapkan SeIf Assessment System. Setelah wajib pajak melaksanakan kewajiban perpajakannya, disinilah peran Sistem Official Assessment dimulai. Pada tahapan ini peran aktif ada pada fiskus atau aparat pajak guna meneliti, memverifikasi atau melakukan proses pemeriksaan atas pelaporan.

Pertengahan tahun 2018 Pemerintah Republik Indonesia menerbitkan peraturan baru di bidang perpajakan yang diperkirakan akan berdampak luar biasa bagi penerimaan pajak. Aturan tersebut dituangkan dalam Peraturan Pemerintah Nomor 23 Tahun 2018. Berbagai tanggapan dari masyarakat muncul setelah keluarnya Peraturan Pemerintah tersebut. Salah satunya adalah mengenai aspek keadilan dalam pengenaan pajak penghasilan yang seolah-olah dikesampingkan dengan munculnya Peraturan Pemerintah tersebut.

Terdapat 3 (tiga) hal yang menjadi pertimbangan pemerintah atas pengenaan pajak penghasilan dengan menggunakan tarif nol koma lima persen dari peredaran usaha bruto setiap bulan serta bersifat final, yaitu: Beban Pajak lebih kecil yang ditanggung oleh pelaku UMKM sehingga dapat mengembangkan usahanya, roda perekonomian dapat diperankan oleh pelaku UMKM sehingga dapat memperluas kesempatan dalam financial dan memperkuat ekonomi, serta pelaku UMKM mendapat waktu untuk mempersiapkan diri sebelum melaksanakan kewajiban dan haknya sesuai dengan undang-undang pajak penghasilan yang berlaku. Sesuai PP ini, pengenaan pajak penghasilan final bermakna artinya setelah pelunasan pajak penghasilan dengan tarif $0,5 \%$ yang dapat dihitung dari peredaran bruto setiap bulannya, jadi kewajiban pajak dari penghasilan tersebut sudah dianggap selesai. Peredaran Bruto adalah penghasilan atau omset atau penghasilan bruto dari usaha. Dalam pengenaan pajak penghasilan, perpajakan yang adil adalah ketika besarnya penghasilan suatu pribadi atau badan maka semakin besar pula pajak terutang yang harus dilunasi.

Persoalannya kemudian ialah konsep keadiIan berdasarkan sesuatu yang abstrak dan sangat subjektif menjadi parameter apakah yang digunakan di dalam mengukur keadilan dalam pemungutan pajak tersebut. Ketidakadilan terjadi karena besar kecilnya penghasilan, dalam hal ini tidak terpengaruhnya besarnya pajak yang terutang dan masih harus dibayar dari penghasilan neto seseorang atau badan. Bahkan dalam tidak menutup kemungkinan dalam suatu situasi rugi, pengenaan $\mathrm{PPh}$ Final seseorang atau badan usaha tetap terutang pajak dan harus segera dilunasinya. Penelitian terdahulu yang releva dengan penelitian ini mengungkapkan bahwa Penerapan sistem administrasi perpajakan modern dalam dimensi prosedur Organisasi, dimensi strategi organisasi, dan dimensi struktur organisasi tidak berpengaruh terhadap kepatuhan wajib pajak. Sedangkan dimensi budaya organisasi terbukti mempunyai pengaruh negatif dan signifikan (Setiana et al., 2010). Menurut (Sudjana, 2020) melakukan penelitian penerapan asas keadilan dan kepastian hukum terhadap pajak penghasilan final bagi usaha kecil, selanjutnya penelitian lain. akan lebih efisien bagi PT. Empat Tujuh Abadi Jaya untuk menghitung pajak penghasilan berdasarkan undang-undang pajak penghasilan apabila dibandingkan dengan pajak penghasilan final (Christian et al., 2019). Penelitian ini bertujuan untuk mendeskripsikan proses penerapan asas keadilan dalam pemungutan pajak penghasilan, yang kedua menjelaskan Peraturan Pemerintah Nomor 23 Tahun 2018 tentang Pajak Penghasilan atas Penghasilan dari usaha yang diterima atau diperoIeh Wajib Pajak yang Memiliki Peredaran Bruto Tertentu sudah memenuhi asas keadilan dalam pemungutan pajak.

\section{METODE PENELITIAN}

Penelitian ini didesain menggunakan penelitian hukum normatif atau penelitian kepustakaan yang dilakukan dengan cara meneliti bahan pustaka atau data sekunder saja. Pendekatan yang digunakan adalah pendekatan Peraturan Pemerintah dan pendekatan undang-undang. Peneliti mempelajari dan mengkaji semua Peraturan Pemerintah0yang memiliki keterkaitan dengan masalah yang diteliti. Dalam hal ini peraturan pemerintah yang dimaksud adalah PP No 23 Tahun 2018 tentang Pajak Penghasilan atas Penghasilan dari usaha yang diterima atau diperoIeh Wajib Pajak yang Memiliki Peredaran Bruto Tertentu. Sumber data yang digunakan adalah Bahan hukum primer yaitu aturan hukum yang diurut secara sistematik terdiri dari perundang-undangan, sedangkan bahan hukum 
sekunder terdiri dari buku-buku, teks, prinsip-prinsip dan tulisan tentang hukum yang terkait pengaaniayaan (Waluyo, 1996)

\section{HASIL DAN PEMBAHASAN}

\section{Penerapan Asas Keadilan dalam Pemungutan Pajak}

Salah satu kriteria dalam merancang sistem perpajakan adalah perlu diterapkan prinsip keadilan. Keadilan pajak (tax equity) berarti bahwa wajib pajak menyumbang fair share (bagian yang wajar) atas cost of government (biaya pemerintah). Keadilan pajak mencakup dua hal yaitu keadilan vertical (vertical equity) dan keadilan horizontal (horizontal equity). Keadilan vertical sering dijelaskan dengan kalimat "seseorang yang penghasilannya lebih besar akan membayar pajak lebih besar". Sementara itu, keadilan horizontal dijelaskan dengan kalimat "dua orang yang mempunyai penghasilan yang sama sehingga akan membayar pajak dalam jumlah sama". Keadilan vertical ditinjau dari subjeknya (orang yang membayar pajak) sedangkan keadilan horizontal dilihat dari aspek objeknya.

Terdapat 2 pendekatan yang dapat digunakan untuk mengukur keadilan pajak yang dibebankan kepada masyarakat yaitu yang disebut degan prinsip manfaat (benefit principle) dan kemampuan membayar (ability to pay principle). Pembebanan jasa kepada konsumen jasa public yang mempunyai pendapat berbeda dapat dilakukan secara professional, progresif, atau regresif (Murthi et al., 2015). Dari sudut keadilan, tarif pajak progresif adalah yang terbaik. Konsep manfaat khusus didasarkan atas pandangan bahwa pajak harus dikenakan pada manfaat khusus yang diterima oleh pembayarnya. Contoh mengenai hal ini adalah pajak tontonan; pajak reklame; opzetten bensin, told dan lain-lain. Kadang-kadang pengenaan pajak yang langsung dikaitkan dengan manfaat ini mengakibatkan biayanya menjadi terlalu tinggi. Dalam hal ini, pajak dikenakan terhadap barang-barang komplementernya, misalnya SWP3D (sumbangan wajib pembangunan dan pemeliharaan prasana daerah). Dalam hal ini, pajak dikenakan terhadap kendaraan bermotor, walaupun tujuan pengenaannya adalah untuk pemeliharaan jalan.

Dalam konsep kemampuan membayar kaitan antara pajak (sisi penerimaan) dengan manfaat (sisi pengeluaran) tidak diperhatikan. Jumlah jasa-jasa yang harus disediakan ditetapkan, kemudian setiap WP membayar sesuai kemampuan. Ada beberapa ukuran untuk menentukan kemampuan mebayar, yaitu (a) penghasilan (income); (b) kosumsi (consumption); (c) kekayaan (wealth). Selain ukuran tersebut di atas, keadaan dari pembayar pajak juga harus diperhatikan. Masalah yang kemudian timbul adalah cara mengukur minimum kehidupan atau kebutuhan primer. Beberapa penulis beranggapan bahwa kebutuhan primer tidak sekedar kebutuhan fisik minimum belaka. Tetapi, termasuk didalamnya adalah semua kebutuhan yang diperlakukan untuk menjamin kehidupan yang sepadan dengan martabat manusia dengan mengindahkan peradaban yang ada. Walaupun demikian, mereka sepakat bahwa pengeluaran mewah dan kebutuhan-kebutuhan social yang membedakan kedudukan seseorang dengan orang lain adalah layak untuk dikeluarkan dari kebutuhan primer. Susunan keluarga juga dipengaruhi oleh faktor-faktor lain, yaitu keadaan keuangan Negara, distribusi pendapatan dan daya beli uang.

Setelah ukuran untuk menentukan kemampuan membayar dapat ditetapkan, persoalan lain yang perlu dipecahkan adalah bagaimana mengkaitkan kemampuan membayar ini dengan pajak yang harus dibayar. Asas keadlan menentukan kemampuan seseorang yang besar harus membayar pajak yang lebih besar pula (Wulandari \& Budiaji, 2017). Ketentuan ini, sering dianggap belum cukup. Pembayaran pajak yang lebih besar tersebut haruslah tidak dipandang dari sisi absolutnya saja, tetapi juga dari sisi relatifnya. Dalam kaitan ini muncul pengenaan pajak yang progresif. Pajak yang dikenakan secara progresif akan terasa lebih adil dibandingkan dengan pengenaan yang proporsional. Apalagi pajak yang dikenakan secara regresif. Progresivitas, proporsionalitas serta regresivitas pajak berkenaan dengan beban pajak yang harus ditanggung dikaitkan dengan kemampuan membayar. Ketiga hal tersebut dapat dihubungkan dengan tarif maupun dasar pengenaan pajak.

Kewajiban utang dan penagihan pajak muncul karena adanya undang-undang yang memberikan hak kepada Negara memungut pajak. Asas pemungutan pajak dapat digunakan sebagai dasar untuk menentuan siapa (Negara mana) yang berhak untuk memungut pajak (Murandika \& Friansyah, 2014). Penggunaan asas yang berbeda antar Negara dapat mengakibatkan timbulnya pajak berganda. Untuk menghindarinya, Negara yang bersangkutan dapat mengadakan perjanjian penghindaran pajak berganda. Disisi lain dapat dijadikan sebagai pedoman untuk menentukan siapa yang berweang 
memungut pajak, asas pemungutan pajak dapat digunakan untuk menentukan siapa yang akan dikenakan pajak dalam suatu Negara. Hal tersebut penting karena menentukan siapa yang akan dikenakan pajak dalam Negara yang mempunyai kewajiban terhadap pajak yang dikenakan Negara. Terdapat tiga sistem yang dapat dipilih dalam pemungutan pajak, yaitu: (1) sistem nyata merupakan sistem yang berdasarkan keadaan yang sebenarnya, (2) sistem anggapan merupakan pajak yang dipungut tanpa menunggu diketahuinya pajak terutang yang sesungguhnya, dan (3) sistem campuran merupakan penggabungan dari kedua cara pemungutan.

\section{Penerapan Asas Keadilan dalam Peraturan Pemerintah Nomor 23 Tahun 2018}

Dalam Negara demokrasi, rakyat sebagai pembayar pajak juga sebagai pengawas langsung dari setiap peraturan perpajakan yang dikeluarkan pemerintah. Sehingga apabila terdapat peraturan perpajakan yang dirasa tidak memenuhi rasa keadilan masyarakat tentu mereka tidak akan tinggal diam karena hal tersebut berdampak langsung terhadap kehidupan individu dalam Negara. Sesuai dengan konsep teori gaya pikul yang diadopsi oleh Pemerintah Indonesia dalam Undang-undang Nomor 36 Tahun 2008 tentang Pajak Penghasilan adalah adanya biaya hidup minimum. Biaya hidup minimum adalah kebutuhan pokok yang tidak bisa ditunda pemenuhnya, seperti: makanan, pakaian dan perumahan. Biaya hidup minimum tercermin dalam diberikannya suatu pengurangan berupa Penghasilan Tidak Kena Pajak (PTKP) yang tergantung pada dua variabel, yaitu status wajib pajak (Kawin/ tidak Kawin) dan Jumlah Tanggungan (maksimal 3 tanggungan).

Peraturan Pemerintah Nomor 23 Tahun 2018 mengatur pengenaan PPh FinaI Pasal 4 Ayat (2) untuk wajib pajak memiliki predaran bruto (omset) sampai 4,8 Miliar Rupiah dalam satu tahun pajak. Pokok-pokok perubahan diantaranya adaIah turunnya tarif PPh FinaI atas Pengahasilan Bruto Tertentu dari semuIa $1 \%$ menjadi $0,5 \%$ dari omzet. PPh Final ini wajib dilunaskan setiap buIan sebelum tanggal 15 buIan berikutnya, tergantung besar rendahnya omzet wajib pajak setiap buIan. Berbeda dengan Peraturan Pemerintah No 46 Tahun 2013 yang tidak membatasi jangka waktu dalam pengenaan tariff Pajak Penghasilan Final. PP No 23 Tahun 2018 ini sudah mengatur tentang jangka waktu pengenaan tariff Pajak Penghasilan Final $0,5 \%$ baik wajib pajak orang pribadi atau badan. Untuk wajib pajak orang pribadi diberikan waktu 7 tahun. Untuk wajib pajak badan berbentuk Firma, Koperadi dan CV diberikan waktu 4 tahun. Sementara untuk wajib pajak berbentu PT (perseroan terbatas) diberikan waktu 3 tahun.

Perubahan PP 46 Tahun 2013 ini karena desakan pelaku usaha khususnya UMKM beranggapan bahwa tarif Pajak Penghasilan ini terlalu tinggi dan memberatkan para pelaku usaha. Sehingga Presiden memerintahkan Dirjen Pajak dan Menteri Keuangan untuk menghitung ulang total penerimaan pajak khususnya dari pelaku UMKM dan berapa persen keringan tarif yang dapat diberikan untuk pelaku UMKM. Dengan penurunan tarif ini diharapkan mampu memberikan keaadilan kepada pelaku usaha khususnya UMKM sehingga wajib pajak mampu membayar sesuai dengan kemampuannya.

Peraturan Pemerintah ini juga dimaksudkan untuk mendorong peIaku UMKM agar lebih ikut berperan aktif dalam kegiatan ekonomi formal dengan cara memberikan kemudahan dan kesederhanaan kepada para peIaku UMKM daIam melakukan pembayaran pajak dan pengenaan pajak (Sunaryo et al., 2018). Selain itu Peraturan Pemerintah ini sudah memberikan keadilan kepada wajib pajak yang memiliki peredaran bruto tertentu tapi sudah dapat melakukan pembukuan. Wajib pajak yang termasuk dalam kategori ini dapat memiliki untuk dikenai Pajak Penghasilan berdasarkan tarif Pasal 17 Undang undang Pajak Penghasilan. Sebuah pilihan yang sebelumnya tidak ada pada PP Nomor 46 Tahun 2013. Peraturan Pemerintah No. 23 Tahun 2018 mencerminkan keadilan dalam pemungutan pajak dibandingkan dengan PP 46 Tahun 2013 karena dalam pengenaan pajak penghasilan UMKM pada akhirnya akan berbasis penghasiIan neto dan dikenakan dengan tarif umum berdasarkan Undang-Undang Pajak Penghasilan yang berlaku.

\section{SIMPULAN DAN SARAN}

\section{Simpulan}

Berdasarkan hasil analisis data, diketahui bahwa Penerapan asas keadilan dalam pemungutan pajak penghasilan, yaitu asas Equality (kesamaan), asas Certainty (kepastian), asas Conveniency of Payment (Kesenangan), dan asas Low Cost of Collection (Efisiensi). Asas yang sangat berhubungan dengan asas keadilan pemungutan pajak adalah Certainty (Asas Kepastian) guna menjamin pelaksanaan pajak 
kepada setiap wajib pajak, yang kedua Peraturan Pemerintah No 23 Tahun 2018 pajak penghasilan dari usaha yang di peroleh wajib pajak telah memenuhi asas keadilan dalam pemungutan pajak. Hal ini dikarenakan adanya penurunan tarih pajak penghasilan final $1 \%$ menjadi $0,5 \%$ dari omzet, harus wajib dibayarkan setiap bulan, jangka waktu pengenaan tarif Pajak Penghasilan Final 0,5\% baik WP orang pribadi atau badan. Untuk WP orang pribadi diberikan waktu 7 tahun. Untuk WP badan berbentuk Firma, Koperadi dan CV diberikan waktu 4 tahun. Sementara untu WP berbentu PT (Perseroan Terbatas) diberikan waktu 3 tahun. Dengan berlakunya peraturan mendapat 3 keuntungan besar bagi UMKM. Pertama adalah lebih kecilnya beban pajak yang ditanggung oleh UMKM sehingga dapat melakukan investasi dalam mengembangkan usahanya, pelaku UMKM berperan menggerakan perekonomi guna memperluas akses finasial dan ekonomi formal dan bagi wajib pajak (WP) dan badan yang teIah melakukan pembukuan dengan benar bisa memilih untuk dikenai pajak penghasiIan berdasarkan tarif normaI diatur pasal 17 UU No 36 pajak penghasiIan.

\section{Saran}

Dari hasil penelitian di atas, peneliti menyarankan kepada pemerintah untuk membuat Kebijakan pemerintah guna membatasi jangka waktu diberlakuan Pajak Penghasilan finaI tarif $0,5 \%$ sudah tepat sehingga wajib pajak cukup waktu untuk belajar melakukan pembukuan. Selanjutnya pemerintah perlu menerapkan bagaimana standar pembukuan untuk UMKM yang Iebih sederhana dari standar akuntansi keuangan perusahaan pada umumnya agar wajib pajak UMKM tidak kesulitan untuk melaksanakan kewajibannya dalam menyelenggarakan pembukuan tersebut.

\section{DAFTAR PUSTAKA}

Arliman. S, L. (2019). Mewujudkan Penegakan Hukum Yang Baik Di Negara Hukum Indonesia. Dialogia Iuridica: Jurnal Hukum Bisnis Dan Investasi, 11(1), 1-20.

Christian, Y. A., Nangoi, G. B., \& Budiarso, N. S. (2019). Implikasi Pengenaan Pajak Penghasilan Final Terhadap Penghitungan Pajak Penghasilan Badan Pada Pt. Empat Tujuh Abadi Jaya. Jurnal Riset Akuntansi Going Concern, 14(1), 10-17.

Murandika, \& Friansyah, M. (2014). Analisis Kebijakan Pemungutan Pajak Hotel atas Rumah Kos ditinjau dari Perspektif Asas-asas Pemungutan Pajak Daerah ( Studi pada Dinas Pendapatan Dan Pengelolaan Keuangan Kota Surabaya ). Jurnal Perpajakan, 1(1), 1-12.

Murthi, N. W., Budhi, M. K. S., \& Purbadharmaja, I. B. (2015). Pengaruh Pajak Progresif Terhadap Perilaku Konsumtif, Basis Pajak, Kepatuhan Wajib Pajak dan Pendapatan Daerah Provinsi Bali. E-Jurnal Ekonomi Dan Bisnis Universitas Udayana, 12, 1001-1028.

Safrina, N., Julkawait, \& Qalbiah, N. (2018). Account Representative "Dua Kaki yang Berdiri di Dua Perahu" dalam Rangka Pencapaian Target Penerimaan Pajak Tahun 2018 (Studi Kasus di Kantor Pelayanan Pajak Pratama Gresik Utara). Jurnal INTEKNA, 18(2), 68-131.

Setiana, S., En, T. K., \& Agustina, L. (2010). Pengaruh Sistem Administrasi Perpajakan Modern Terhadap Kepatuhan Wajib Pajak. Jurnal Akuntansi, 2(2), 134-161.

Sudjana. (2020). Penerapan Asas Keadilan dan Kepastian Hukum Terhadap Pajak Penghasilan Final Bagi Usaha Kecil. Jurnal Hukum Sasana, 6(2), 111-128.

Sunaryo, K., Gantino, R., Rova, Y., \& Prayoga, N. (2018). Upaya Peningkatan Kinerja UMKM dan Koperasi Provinsi DKI Jakarta dengan Adanya PP NO . 23 Tahun 2018. Jurnal Abdimas, 5(4), 235-241.

Waluyo, B. (1996). Penelitian Hukum Praktek. Sinar Grafika.

Wulandari, S., \& Budiaji, A. (2017). Pengaruh Persepsi Keadilan Pajak dalam Peraturan Pemerintah Republik Indonesia Nomor 46 Tahun 2013 terhadap Kepatuhan dalam Memenuhi Kewajiban Perpajakan. Jurnal Ekonomi Islam, 8(239-268). 